\title{
CORRESPONDENCE
}

\author{
Addiction to aerosol treatment \\ P O Brennan, MRCP; H Wickramasinghe, \\ MD, and H J Liebeschuetz, FRCP....... 1877 \\ Long term domiciliary oxygen \\ treatment \\ D C Flenley, FRCP. . . . . . . . . . . 1877 \\ Public health advocacy \\ A Scott-Samuel, MFCM. \\ Treatment of detainees in South Africa \\ S P Sashidharan, MRCPSYCH; J Dommisse, \\ MD; M E Bennun, LlB; M S C Nelemans. . 1879 \\ Deaths associated with intrauterine \\ contraceptive devices \\ G Roberts, FRCOG; S Brearley, FRCS, and \\ M B Yaghmour............... 1880 \\ Whooping cough and pertussis \\ vaccination \\ A H Griffith, MD; N W Preston, FRCPATH . . 1881
}

Risks from radioiodine treatment for thyrotoxicosis

E S Williams, MD, and K E Halnan, MD . . 1882

Head injuries in adults

A D Mendelow, FRCS, and others; K T

Evans, FRCR, and others............. 1882

Mean platelet volume in myocardial

infarction

H A Cameron, MRCP, and others....... 1883

Protein creatinine index and Albustix

in assessment of proteinuria

$\mathrm{T}$ Wilkin, MD, and others...

Multiple endocrine neoplasia associated

with von Recklinghausen's disease

I $\mathrm{H}$ Ellis, $\mathrm{BB}_{\ldots \ldots \ldots \ldots \ldots \ldots \ldots \ldots \ldots} 1883$

The big spenders

D R T Gundry, MRCGP. .
Payments to doctors and the responsibilities of ethics committees J G Ball, FRCGP, and E S Snell, FRCP . . . . . 1884

\section{Junior doctors' hours of work}

A Bristow, FFARCS, and M Rees, MRCP ; P D

Welsby, MrCP................ 1884

Points Early trials of streptomycin (J G

Scadding); The end of clinical freedom

(D H Spodick); Unreviewed reports (C S

Good); Unsolicited mail (R C Gupta);

Multiple endocrine neoplasia associated

with von Recklinghausen's disease (A

Boissonnas and others); Villa Serbelloni

(A W Franklin); Candidiasis in heroin abusers (M Mackay); Association between use of cotton tipped swabs and cerumen plugs (P D Bull and A S Jones)......... 1885

We may return unduly long letters to the author for shortening so that we can offer readers as wide a selection as possible. We receive so many letters each week that we have to omit some of them. Letters should be typed with double spacing between lines and must be signed personally by all their authors, who should include their degrees. Letters critical of a paper mav be sent to the authors of the paper so that their reply may appear in the same issue.

Correspondents should present their references in the Vancouver style (see examples in these columns). In particular, the names and initials of all authors must be given unless there are more than six, when only the first three should be given, followed by et al; and the first and last page numbers of articles and chapters should be included.

\section{Addiction to aerosol treatment}

SIR, - The case reported by Dr P J Thompson and others (19 November, p 1515) highlights the problem of abuse of inhalers by young asthmatics, and I agree that less severe forms of abuse may be common, especially in younger age groups.

Over the past few years in an asthma clinic at the Sheffield Children's Hospital I have noted five patients who abused their salbutamol inhalers, though less severely than the case reported (table). They admitted taking

Details of five patients who abused their salbutamol inhalers

\begin{tabular}{cccc}
\hline Case No & $\begin{array}{c}\text { Age at peak } \\
\text { dose }\end{array}$ & Sex & $\begin{array}{c}\text { Maximum } \\
\text { daily dose }\end{array}$ \\
\hline 1 & 13 & $\mathrm{~F}$ & 30 \\
2 & 15 & $\mathrm{~F}$ & 200 \\
3 & 12 & $\mathrm{~F}$ & 20 \\
4 & 12 & $\mathrm{~F}$ & 28 \\
5 & 11 & $\mathrm{M}$ & 30 \\
\hline
\end{tabular}

increased doses not because of increased symptoms, but because they "needed it," and in one case because it made the thrillers on television more exciting. None of the patients developed increased frequency or severity of attacks after their salbutamol intake was reduced and more closely monitored by changing aerosol treatment to inhalation capsules.

None of the patients using beclomethasone inhalers (three of the five reported) abused these, and although some of the effects the patients desired from their salbutamol inhalers may have been due to the fluorinated hydrocarbons, some may be attributed to the sal- butamol. This is known to cause hyperactivity and a manic mood in young children and has also been reported to have antidepressive effects in some patients. ${ }^{1}$ We have also heard of abuse of salbutamol in non-asthmatics, and on one occasion this was not associated with the fluorinated hydrocarbons. ${ }^{2}$

Salbutamol has been a valuable and safe part of our treatment for asthma over the past few years, and it is a great shame that it is apparently being abused in this way by a small percentage of people. I hope this will not overshadow its usefulness.

P O BRENNAN

Children's Hospital,
Sheffield S10 2TH

Widlocher D, Lecrubier Y, Jouvent R, et al. Antidepressant effect of salbutamol. Lancet 1977;ii: $767-8$ ${ }^{2}$ Brennan P. Inhaled salbutamol: a new form of drug
abuse? Lancet 1983;ii:1030-1.

SIR,-We would like to report a case of abuse of salbutamol in a child further to that reported by Dr P J Thompson and others (19 November, p 1515).

An 11 year old boy had had asthma and eczema since infancy. He had been using a salbutamol inhaler, as required, since the age of 7 but received no regular prophylaxis. Suddenly his mother noted that he was using two to three inhalers a week whereas previously one had lasted at least a month. She was the more concerned as he had no audible wheeze. He had had no previous experience of drug abuse. Fortunately, within two weeks, his general practitioner changed his treatment to sublingual isoprenaline.
When questioned the boy admitted that he continued inhaling salbutamol until he experienced euphoria. This took at least 20 to 30 "puffs" at a time. On two occasions he experienced hallucinations. He never had palpitations or withdrawal symptoms and only once had muscle tremors. One or two inhalations of salbutamol relieved bronchospasm even during the short period of abuse, suggesting that no tolerance had developed. His treatment was successfully changed to Becotide rotacaps and he has remained well.

This boy had a non-compulsive dependence on salbutamol inhalers that appeared to be psychological as there were no withdrawal symptoms to suggest physical dependence. As Dr Thompson suggests in his case, it is likely that our patient was dependent on the fluorinated hydrocarbon used as a propellant rather than on the salbutamol itself as the predominant symptoms of salbutamol overdosage were missing in this child.

It is necessary to be alert to the possibility of dependence on aerosol inhalers among children with asthma.

Southend Hospital,
Westcliff-on-Sea,

H WICKRAMASINGHE H J LIEBESCHUETZ

Essex SSO ORY

\section{Long term domiciliary oxygen treatment}

SIR,-The ability of Dr Ian W B Grant's opinions to fill your correspondence columns is self evident. His letters of 6 February 1982 (p 417), 3 September 1983 (p 685), and 22 October 1983 (p 1223) on oxygen in the 
home could be taken to imply that failure to respond to his criticisms indicates that they are accepted. As one of those named in his comments, may I be allowed to summarise the scientific data that lead me to reject his opinion that recommendations for this treatment are based on "inadequate evidence" (his words).

In his letters of 6 February 1982 and 3 September 1983 Dr Grant criticises the MRC trial of long term domiciliary oxygen therapy. ${ }^{1}$ Firstly, he claims that the trial was "not properly controlled," as compressed air was not given to the control group. This was considered by the MRC working party, but rejected for three reasons: it would be illegal to disguise air as oxygen in cylinders for patient use, or vice versa; "medicinal" compressed air would have been needed for $1513601\left(48 \mathrm{ft}^{3}\right)$ cylinders a week for 42 patients for up to five years, at much higher cost than oxygen; and on scientific grounds, as the main variable studied was entirely objective-the patient's date of death

Dr Grant further criticises the trial on the grounds that: "The patients receiving oxygen must have reduced their cigarette consumption considerably while the untreated controls would have no incentive to do so." This was not shown by the patients' answers to questions on their smoking habits in the MRC trial. I am, however, sceptical of such answers, as at least in Edinburgh many of our bronchitic patients continued to smoke (as shown by high carboxyhaemoglobin concentrations despite their denial when responding to our questions (fig 1). We have reported that

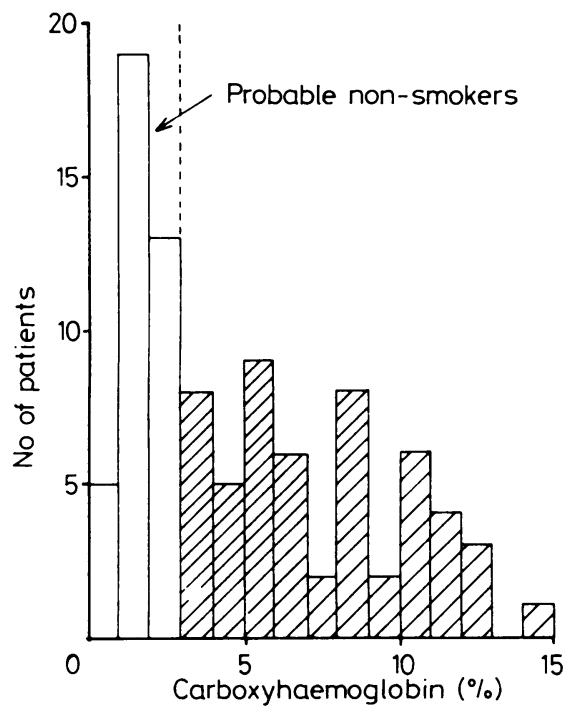

FIG 1-Carboxyhaemoglobin concentrations in 91 consecutive patients attending the outpatient clinic for chronic bronchitis and emphysema in the Royal Infirmary of Edinburgh in 1981. All patients had been advised to stop smoking and claimed to have done so; carboxyhaemoglobin concentrations above $3 \%$ are unlikely to occur in patients who are not heavy cigarette smokers.

long term oxygen, given over one year, reduced haematocrit only in those severely hypoxic patients in whom carboxyhaemoglobin also fell as they did indeed give up smoking. ${ }^{2}$ If the apparent effects of oxygen in improving survival in the treated patients were due only to their stopping smoking, then this effect should be apparent without the oxygen. I know of no evidence that life is prolonged by stopping smoking in those with chronic bronchitis and emphysema complicated by severe hypoxaemia, carbon dioxide retention, and cor pulmonale where the smoking cessation has been verified by measurements of carboxyhaemoglobin and comparisons made with a similar group who did not give up smoking. Does Dr Grant have such evidence? In their studies on use of the oxygen concentrator in 14 patients over 12 months, Dr

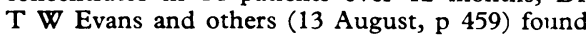

carboxyhaemoglobin saturation from $1 \cdot 7-11 \cdot 5 \%$ in the morning after oxygen given overnight and $2 \cdot 4-14 \cdot 2 \%$ in the afternoon, when they had been off oxygen for at least two hours. Some of their patients thus clearly did continue to smoke, despite warnings, again suggesting that $\mathrm{Dr}$ Grant's assumption that the treated patients in the MRC study all stopped smoking may be untrue, so that any benefits could not therefore be attributed to this alone, rather than to the oxygen treatment.

Dr Grant further states: "The treatment did not produce any other measurable clinical benefit" for which he quotes the failure to reduce hospital stay, or increase in days at work in the treated group, as compared with the control patients. As the MRC report points out these patients were under intensive outpatient supervision and were admitted to hospital readily at the first sign of exacerbation, in both the control and treated groups. Their mean age (for men) was 58 years in the treated group and 56 years in the control group, and they had severe airways obstruction (table), which oxygen could not improve, and in most cases had been out of work for several years before entry to the study. Although oxygen during exercise can reduce minute ventilation in bronchitic patients with hypoxia ${ }^{3}$ and improve effort dyspnoea in bronchitic patients with normal oxygen content but with airways obstruction, ${ }^{4}$ it would have indeed been remarkable if many of such severely disabled patients had returned to the manual work that most of them were accustomed to. None the less, a few younger patients did go back to work. Quality of life is notoriously difficult to assess, and Dr Grant's opinion (for which he offers neither evidence nor personal clinical experience) that long term domiciliary oxygen only prolonged "the survival of severe respiratory cripples, which must have been a poor recompense for them having to be tethered to oxygen cylinders for 15 hours a day" is at variance with the experience described in the MRC report, my own continued experience of these patients, and that described by many others in North America, ${ }^{5}$ by Duwoos in France, ${ }^{6}$ and by Matthys and by Jurgens in Germany, ${ }^{6}$ all of whom have had experience in treating considerable numbers of these patients with long term oxygen. As some eight hours of the "tethering" takes place when in bed, and much of the rest by trailing $1 \mathrm{~cm}$ plastic tube from the concentrator to where the patient is in his house or garden, this has not been a problem in practice. These patients are not bedbound. Again, for example, a recent patient continued in legal practice for three years by using liquid oxygen at work, having previously been about to retire prematurely as he was housebound by his cor pulmonale.

Then: "This treatment would be enormously expensive if made freely available, and the expenditure would not be offset by more than a miniscule financial return as most of the survivors would be unemployable." Dr Evans and others (13 August, p 459) report that the capital cost of the concentrator was $£ 1200$, with a yearly running cost of $£ 150-200$, and a servicing cost of $£ 84$ a year, and quarterly home visits by the hospital staff costing $£ 68$ per patient per year. A current quotation for hire of a concentrator and ancillary equipment, with full servicing and two back up cylinders for stand by is $£ 1020$ per patient per year (figures provided by British Oxygen Company, November 1983). ${ }^{6}$ Provision of 13601 oxygen cylinders through family practice committees in England in 1978-9 varied 10-fold between area health authorities and bore no relation to respiratory disease mortality or degree of urbanisation. ${ }^{7}$ Such apparently haphazard provision of domiciliary oxygen in England, which cost $£ 4.9 \mathrm{~m}$ in $1980-1^{8}$ (which could possibly be equivalent to $£ 9 \mathrm{~m}$ for the whole United Kingdom in 1983), might imply that long term domiciliary oxygen for chronic cor pulmonale could be provided for many more patients without extra cost, if this service and indications for this treatment were rationalised. Most of this existing provision of home oxygen was for less than one week's duration, and the haphazard distribution must raise questions as to the medical indications for such short term treatment. Even if half of this cost were deflected to long term domiciliary oxygen treatment for such patients as those studied in the MRC trial and concentrators were used, around 4000 or more patients could be treated each year in the United Kingdom within the existing budget for domiciliary oxygen. Would it not be reasonable for a Health Service concerned with maintaining patient care at the most economical cost to explore these possibilities and to find out what existing provision for home oxygen is being used for today?

In both the MRC report and in my personal writing it has been emphasised that the trial results apply only to patients with chronic bronchitis and emphysema, with proved hypoxaemia, and cor pulmonale, in whom the forced expiratory volume in one second is below 1.21 , and oxygen pressure between 40 and $55 \mathrm{~mm} \mathrm{Hg}(5 \cdot 3-7 \cdot 3 \mathrm{kPa})$, these measurements and body weight, etc, being constant over a three week period, when the patient is in a stable state. ${ }^{1-11}$ In my own practice this treatment is considered only if the patient also has carboxyhaemoglobin values below $3 \%$ on these two occasions, so excluding current cigarette smokers. As the MRC report recommended, such respiratory and physiological measurements should be made before the treatment is considered. Your readers must judge if the above adds up to the "enormous expense" if the treatment were "freely available" which Dr Grant fears.

Although clearly the financial implications are important, as detailed above, I cannot accept the Neitzchian morality of Dr Grant's implication that long term treatment should be denied to a patient on the grounds that the costs cannot be recovered as the patient would still be unemployable. Application of this principle would presumably close our geriatric services tomorrow as well as those for the long term care of the chronic sick. I find it hard to believe that this is what Dr Grant really wants.

It seems reasonable to use all evidence available from controlled trials to evaluate this new treatment. When one compares the important physiological variables in the only two such trials it is seen (table) that the patients were similar in their degree of hypoxia, chronic airflow limitation, and pulmonary hypertension, but that the British patients were younger, with more carbon dioxide retention than those in North America. ${ }^{12}$ When we plot the

Mean values of physiological variables (when breathing air) at entry to trials of long term domiciliary oxygen treatment

\begin{tabular}{|c|c|c|c|c|}
\hline \multirow[b]{2}{*}{$\begin{array}{l}\text { No of hours' treatment } \\
\text { (out of } 24 \text { ) }\end{array}$} & \multicolumn{2}{|c|}{ MRC (men) } & \multicolumn{2}{|c|}{$\begin{array}{c}\mathrm{NIH} \text { (men } \\
\text { and women) }\end{array}$} \\
\hline & 15 & 0 & 24 & 12 \\
\hline $\begin{array}{l}\text { No of patients } \\
\mathrm{FEV}_{1}(\mathrm{l}) \\
\mathrm{PaO}_{2}(\mathrm{~mm} \mathrm{Hg}) \\
\mathrm{PaCO}_{2}(\mathrm{~mm} \mathrm{Hg}) \\
\mathrm{PAP}(\mathrm{mm} \mathrm{Hg})\end{array}$ & $\begin{array}{r}33 \\
0.76 \\
50 \\
55 \\
34\end{array}$ & $\begin{array}{r}33 \\
0.65 \\
52 \\
53 \\
35\end{array}$ & $\begin{array}{r}101 \\
(0 \cdot 8) \\
51 \\
43 \\
30\end{array}$ & $\begin{array}{r}102 \\
(0 \cdot 8) \\
52 \\
44 \\
29\end{array}$ \\
\hline
\end{tabular}

$\mathrm{FEV}_{1}=$ forced expiratory volume in one second; $\mathrm{PaO}_{2}=$ arterial oxygenation; $\mathrm{PaCO}_{2}=$ arterial $\mathrm{CO}_{2}$ tension Conversion. traditional to SI $1 \mathrm{~mm} \mathrm{Hg} \approx 0.133 \mathrm{kPa}$.

survival curves in the two studies on the same graph (fig 2), however, the effect of the dose of oxygen (taken as the duration that the oxygen was given in each 24 hour period) allows the conclusion that no oxygen is bad, oxygen for some of the time is better, but oxygen for most of the time is best of all, at least so far as prolonging survival is concerned. If the improved survival with oxygen in patients in the MRC trial was indeed spurious, I suggest that the response would be unlikely to be related to the dose of oxygen in this fashion. At 38 months, when the American study was stopped as the advisers considered it unethical to continue with only nocturnal oxygen treatment, it seems that the survival of those receiving oxygen for over 19 hours in every 24 hours, was possibly double that of the physiologically similar (but not identical) patients in the MRC study who received no oxygen. These studies combine experience in 290 patients studied for up to 38 months and 68 months. ${ }^{12} 1$ In my view the results (fig 2) 


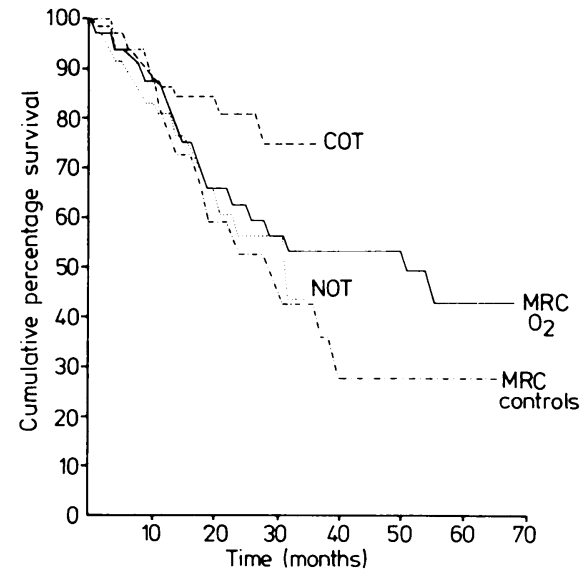

FIG 2-Survival curves from the British (MRC working party (ref 1)) and American (Nocturnal Oxygen Therapy Trial Group (ref 12)) trials for men under the age of 70 receiving oxygen for more than 19 hours (COT), 12 hours (NOT), or 15 hours $\left(\mathrm{MRC}_{2}\right)$ in the 24 hour day or not receiving oxygen (MRC controls). I thank Dr T L Petty for providing this data from the NOTT study.

indicate that this treatment is worth considering for such carefully selected patients. Research efforts should now be directed to how to provide this treatment most economically and at most convenience to the patients, and how to improve selection of those most likely to benefit. ${ }^{13}$

I submit that this treatment is indeed based on sound scientific considerations and that the economic case may be best considered in light of existing expenditure on home oxygen treatment, where, I suspect, current clinical practice is much more in need of critical appraisal.

D C Flenley

\footnotetext{
Department of Respiratory
Medicine,
}

City Hospital,

Medical Research Council Working Party. Long term domiciliary oxygen therapy in chronic hypoxic cor pulmonale complicating chronic bronchitis and emphysema. Lancet 1981 ;i :681-6.

Calverley PMA, Leggett RJ, McElderry L, Flenley DC. Cigarette smoking and secondary polycythaemia in hypoxic cor pulmonale. Am Rev Respir Dis

King AJ, Cooke NJ, Leitch AG, Flenley DC. The to treadmill exercise in chronic respiratory failure. Clin Sci 1973;44:151-62.

Woodcock AA, Gross ER, Geddes DM. Oxygen relieves breathlessness in "pink puffers." Lancet $1981 ; \mathrm{i}: 907-9$.

Anthonisen NR. Long term oxygen therapy. Ann Intern Med 1983;99:519-27.

Leitch AG, ed. The lung under attack. Proceedings of the Societas Europaea Pneumologica convention, (in press).

Williams BT. Geographical variations in the supply of domiciliary oxygen. Br Med f 1981;282:1941-3. Secretary of State for Social Services. Parliamentary
written reply. House of Commons official report written reply. House of Commons official repor (Hansard) 1981 June 12:6: col 227. (No 120.)

Flenley DC. Recent advances in respiratory medicine. Postgrad Med f 1983;59:1-16

BrMed f 1983;286:871-5.

BrMed f 1983;286:871-5.

emphysema. In: Flenley DC, Petty advances in respiratory Churchill Livingstone, 1983:173-91.

* Nocturnal Oxygen Therapy Trial Group. Continuous or nocturnal oxygen therapy in hypoxemic chronic obstructive lung disease. A clinical trial. Ann Intern Med 1980;93:391-8.

Ashutosh K, Mead G, Dunsky M. Early effects of oxygen administration and prognosis in chronic Am Rev Respir Dis 1983;127:399-404.

\section{Public health advocacy}

SIR,-Minerva (26 November, p 1633) has done public health an important service in raising the question of whether health authority officers should speak out when they believe that their employer's policies are wrong. During the past decade many community physicians have expressed their concern at the way in which the 1974 Health Service reorganisation turned the public advocate who was the medical officer of health (accountable to a democratically elected local authority) into the "faceless bureaucrat" model of the community physician, distanced from the public gaze in unaccountable "quango" health authorities.

It is high time that community physicians and those who represent them spoke out in order to reopen the health of the public to public debate.

Alex Scott-Samuel

Radical Community Medicine,
Liverpool L18 6HP

\section{Treatment of detainees in South Africa}

SIR,-Professor Strauss's defence (8 October, p 1066) of the Medical Association of South Africa (MASA) against charges of unethical practices by its members must be put in its proper perspective.

MASA's recent inquiry into aspects of medical involvement in the detention and interrogation of political dissidents is claimed to be a demonstration of good faith and sincere desire for reform on the part of this organisation. MASA's record on ethical issues in relation to medicine belies this claim. South African doctors and MASA have always avoided considering the contradiction between present day goals, concepts, and approaches of public health and apartheid. As a result, South African doctors and organisations like MASA stand idly by while apartheid leads to "preventable deaths not being prevented and treatable diseases not being treated." Medical ethics is not ;ust a matter of individual failures or follies; it also concerns medicine's role in society.

The recent report from MASA is an attempt to placate fears expressed in the West about the collusion between some South African doctors and the apartheid régime in pursuance of its racist policies. ${ }^{2}$ The torture of political detainees and the involvement of doctors and psychiatrists in "treating" the victims of such abuses have received much attention recently. ${ }^{3} 4$ MASA's report is a direct result of this increasing international concern. After all, there has been little change in the system of detention in South Africa for 20 years, and during this time more than 50 political detainees have died in police custody. Medical care of these detainees was exclusively the responsibility of district surgeons, and their failure to speak out against the harsh methods used by the security police that resulted in physical and psychiatric damage to the detainees gave substance to the allegation that these doctors were part of the apparatus of indefinite detention operative by virtue of the Internal Security Act. MASA has condoned such collusion between doctors and police authorities in the past, and questions about medical impartiality, confidentiality, and ethical practice have not been major concerns for this organisation.

The report on medical care of prisoners and detainees by the ad hoc committee of MASA will unfortunately do nothing more than give medical legitimacy to the detention and other procedures as they already exist. It does not suggest any fundamental change in the system of detention and does not offer additional protection for those detainees who have recently found themselves in medical and psychiatric wards of hospitals. Although MASA's report recognises the lack of legislative safeguards for prisoners and the health hazard of physical and psychological torture, the recommendations of the committee could lead to a closer involvement of doctors in isolation and interrogation procedures (see paragraphs 6.2 and 6.5 of the report).
The most important question is how MASA and other medical bodies will respond if the abuses are continued with the collaboration and connivance of a few doctors. In November 1963, when 60 medical specialists, psychiatrists, and psychologists in South Africa sent an appeal to the Minister of Justice for the abolition of solitary confinement under the detention laws, the then prime minister, Dr Verwoerd, rejected the recommendation of the medical experts and stated: "The medical profession must not be dragged in where it is nothing else than an attempt to make political propaganda in connection with any matter. Here is an attempt to attack the government. It is therefore not purely professional diagnosis which we shall allow to influence our judgment."

\section{S P SASHIDHARAN}

Royal Edinburgh Hospital,

1 World Health Organisation. Apartheid and mental health care. Geneva: WHO, 1977. (MNH/77-5).

edical Association of South Africa. Medical care of prisoners and
suppl:21 May.

${ }^{3}$ Catholic Institute of International Relations. Torture in South Africa. London: Catholic Institute of International Relations, 1982 .

- Sashidharan SP. Psychiatrists and detainees in South Africa. Lancet 1983;i:128.

Verwoerd HF. Parliamentary reply. House of Assembly
Debates 1964;Jan $21:$ col 22 .

SIR,-Professor S A Strauss (8 October, p 1066) jumps to the defence of the Medical Association of South Africa (MASA) against an attack by $\mathrm{Mr}$ Mervyn E Bennun (27 August, p 611). Mr Bennun was right when he said that Dr Snyman and the other doctors clearly "thought that MASA would support their interpretation of their ethical duties towards political detainees"-as shown by the fact that MASA has not even questioned any of their actions, let alone started disciplinary proceedings against them. The fact that MASA has since produced a report of a committee recommending certain tentative legal and medical protections against abuse of political detainees -only after six years of intense international pressure-in no way casts doubts on $\mathrm{Mr}$ Bennun's assumptions about MASA's views on political detainees.

Professor Strauss makes much of the exception to the rule of professional confidentiality and tries to make out that these breaches "have been in the interest of the detainee." The South African legal-police-detention system is seen by him to be totally benign and beneficial to everyone. He fails to mention that most if not all of the "several doctors" who "have recently brought an application in the Supreme Court to compel the Medical and Dental Council to initiate disciplinary proceedings against the doctors involved" in the Biko case, were not only not members of MASA but are non-members precisely because they have considered MASA to be sitting on its hands for all these years on this highly contentious ethical issue.

When MASA has not acted at all against any of the "handful of doctors" (whom Professor Strauss claims are unrepresentative of MASA) $\mathrm{Mr}$ Bennun is correct in assuming that MASA condones their actions and is in accord with them. And though not all peaceful and nonviolent opposition to apartheid is regarded by South African law as treason, terrorism, or subversion, clearly a large portion of such opposition is punished with detention, bannings, imprisonment, and death (officially or 